Крестьянінов Є. В., Срмакова Л. М., Антал Т. В.

УДК 633.15: 631.82 : 330.131.5

ЕКОНОМІЧНА ТА ЕНЕРГЕТИЧНА ЕФЕКТИВНІСТЬ ВИРОЩУВАННЯ КУКУРУДЗИ ЗАЛЕЖНО ВІД МІНРАЛЬНИХ ДОБРИВ ТА ПОЗАКОРЕНЕВОГО ПІДЖИВЛЕННЯ ПОСІВІВ Є.В. КРЕСТЬЯНІНОВ, здобувач

Л. М. СРМАКОВА, кандидат сільськогосподарських наук, доцент

Т. В. АНТАЛ, кандидат сільськогосподарських наук, доцент

Національний університет біоресурсів і природокористування Украӥни

E-mail: v.krestianinov@gmail.com

https://doi.org/10.31548/dopovidi2020.05.006

Анотація. У статті наведено результати досліджень щуодо визначення економічної та енергетичної ефективності технологї̈ вирошування кукурудзи за застосування мінеральних добрив - $N_{158} P_{52} K_{52}($ Фон) та піджсилення посівів добривами Нутрімікс (1,0 кг/га), Нутрібор (0,5 кг/га) та Мікро- Мінераліс Кукурудза (1,0 л/га). Застосування мінеральних добрив та позакореневого підживлення посівів добривами з мікроелементним складом забезпечило прибуток на рівні 41773 - 47064 грн./га; рівень рентабельності 142-151\% та коефіцієнт енергетичної ефективності Кее - 4,73-4,87 у гібриду Аякс та у гібриду Оржиця 237 МВ зазначені показники становили відповідно: 39298-44787 грн./га, 144-155\% ma (Кее) 4,56 -4,72. Такий діапазон показників обумовлений застосуванням добрив у підживленні розрізнено та сумісно за одно- $i$ дворазового застосування у фенологічні фази 4, 8 ma 4 i 8 листка. Добрива з мікроелементами в позакореневому підживленні забезпечували підвищення економічної та енергетичної ефективності вирощування кукурудзи.

Ключові слова: кукурудза, урожайність, удобрення, економічна ефективність, вартість продукиії, прибуток, рівень рентабельності

Актуальність. Визначальним для аграрної галузі в останні роки $є$ зростання ролі зернових культур.

На аграрному ринку зернові культури зберігають провідні позиції в експорті, переробці і внутрішньому споживанні, що доводить їх стратегічно важливу роль у забезпеченні продовольчої i економічної безпеки країни [9].

Кукурудза за часів незалежності в балансі виробництва зерна посіла домінуюче місце і становить 40-50 \%.
Своєї ваги в рослинницькій галузі набирала досить стрімко. 32005 року вона збільшила свої основні виробничі параметри в рази: площі виросли 3 1, 66 млн./га до 4,5 млн./га у 2017 році; валовий збір із 7,2 до 26 млн. т (2016 р.), а в 2013 році було одержано рекордний збір зерна - 30 млн. т. Незважаючи на те, що кукурудза має високий потенціал урожайності, реалізація його не висока та залежить від цілого ряду чинників, серед яких чільне місце 
Крестьянінов С. В., Срмакова Л. М., Антал Т. В. займає удобрення та добір гібридів, адаптованих до умов вирощування [8].

Основними факторами, на яких нами була зосереджена увага у дослідженнях, є застосування добрив та використання нових гібридів, які забезпечують отримання високих урожаїв за оптимізації технологічних прийомів вирощування.

Аналіз останніх досліджень та публікацій. Рослини кукурудзи потребують для свого живлення макро- й мікроелементи. Основними елементами живлення є азот, фосфор, калій, а також кукурудза чутлива до нестачі цинку, середньо чутлива до нестачі бору, міді й марганцю.

Вченими доведено, що зернова кукурудза особливо чутлива до мікроелементів, тому їх застосування неодмінно потрібне при піi вирощуванні [3,7]. Важливим є проведення позакореневих підживлень посівів в період вегетації культури сучасними добривами 3 мікроелементним

складом.

Мікроелементи забезпечують поживу і захист сходів до і після їх появи від несприятливих погодних чинників та зменшують їх негативну дію, активізують i підтримують фотосинтез та азотфіксацію, підвищують ефективність макродобрив, створюють антистресовий ефект від застосування пестицидів, збільшують кількість i якість урожаю. Оптимальне живлення підвищує врожайність на 15-20\% $[1,5]$.

Економічні варіанти технологій, які забезпечують окупність затрачених ресурсів з максимальною ефективністю, необхідно розробляти на основі оцінки результатів досліджень та всебічного аналізу окремих блоків i елементів технологічного процесу. Це забезпечує збільшення обсягів виробництва продукції, покращення іiі якості та зниження виробничих витрат [6].

Агротехніка вирощування будьякої сільськогосподарської культури завжди повинна бути спрямована на зменшення витрат та збільшення прибутку. Виробництво вважається рентабельним, якщо відношення чистого прибутку до виробничих витрат (тобто рівень рентабельності) дорівнює понад 25\%. Кукурудза завжди була економічно вигідною зерновою культурою. Проте витрати праці i засобів виробництва на иï вирощування суттєво вищі, ніж при вирощуванні інших зернових культур. Це пояснюється тим, що для отримання високої врожайності цієї культури слід вносити підвищені дози мінеральних добрив, що призводить до збільшення собівартості. Розрахунки витрат на вирощування кукурудзи за окремими статтями показують, що найбільша питома вага припадає на добрива, засоби захисту рослин від шкідливих організмів i паливно-мастильні

матеріали 
Крестьянінов Є. В., Срмакова Л. М., Антал Т. В. (відповідно 40 - 48 і 19 - 25\%), механізовані роботи $(47-49 \%), 3$ них на обробіток грунту 15 - 19\% і догляд за посівами $8-12 \%$.

Важливим фактором, який визначає економічну ефективність вирощування гібридів кукурудзи i, перш за все, обумовлює витрати на сушіння, є показник вологості зерна [10].

3 метою об'єктивного обгрунтування найбільш раціонального поєднання агрозаходів, що взяті нами на вивчення, була визначена економічна ефективність досліджуваних елементів технології (гібриди та добрива 3 макро- i мікроелементним складом) 3 використанням нормативних витрат матеріально-технічних ресурсів при вирощуванні кукурудзи на зерно. Загальні норми виробітку, ціни на виконані види робіт використовуються відповідно до рекомендованих нормативів для виробництва $[2,4]$.

Мета досліджень полягала у встановленні економічної та енергетичної ефективності технології вирощування кукурудзи гібридів Аякс та Оржиця $237 \mathrm{MB}$ за застосування мінеральних добрив в нормі $\mathrm{N}_{158} \mathrm{P}_{52} \mathrm{~K}_{52} \quad$ (Фон) та підживлення посівів добривами Нутрімікс (1,0 кг/га), Нутрібор (0,5 кг/га) та Мікро - Мінераліс Кукурудза (1,0 л/га).

Методика

досліджень.

Дослідження проводилися в умовах
ТОВ «Українська молочна компанія» Київської області Згурівського району. Грунт дослідної ділянки темно-сірий опідзолений. Предметом дослідження були гібриди кукурудзи Аякс та Оржиця $237 \mathrm{MB}$ - К. Удобрення застосовували відповідно до схеми досліду. Повторність досліду чотириразова. Площа облікової ділянки - 50м². Гібриди вирощувалися на загальному фоні мінеральних добрив $\mathrm{N}_{158} \mathrm{P}_{52} \mathrm{~K}_{52}$. Позакореневе підживлення посівів кукурудзи проводили у фази 4, 8 та 4 i 8 листка мікродобривами Нутрімікс (1 кг/га) та Нутрібор (0,5 кг/га) i добривом Мікро-Мінераліс Кукурудза у зазначені фази з нормою внесення 1л/га.

\section{Основні}

результати

дослідження. При розрахунку економічної ефективності досліджуваних елементів технології вирощування кукурудзи нами були вивчені та узагальнені усі види витрат, встановлена їх структура у відсотковому співвідношенні та виявлено вплив на економічну ефективність вирощування гібридів кукурудзи позакореневих підживлень добривами 3 мікроелементним складом.

У середньому за роки досліджень (2015-2017 рр.) загальні виробничі витрати при вирощуванні гібриду Аякс становили від 29507 грн/га за варіанту контролю до 31096 грн/га за варіанту застосування дворазового підживлення посівів у фенологічні 
Крестьянінов С. В., Срмакова Л. М., Антал Т. В. фази 4 та 8 листка добривами Нутрімікс та Нутрібор і МікроМінераліс Кукурудза (табл. 1). За вирощування гібриду Оржиця 237 МВ даний показник варіював в межах 27262 - 28893 грн/га (табл.2).

Ріст урожайності кукурудзи супроводжувався i зростанням вартості валової продукції 31 га посіву. Найнижчою вона була у варіанті контролю у обох досліджуваних гібридів та відповідно становила у гібриду Аякс - 71280 та гібриду Оржиця 237 MB 66560 грн/га.

Застосування добрив Нутрімікс, Нутрібор та Мікро-Мінераліс Кукурудза сприяло підвищенню урожайності, що в свою чергу забезпечило і отримання найбільшої вартості валової продукції, яка у гібриду Аякс становила 78160 та гібриду Оржиця 237МВ 73680 грн/га.

Встановлено, що прибуток від реалізації виробленої продукції залежав від рівня урожайності та виробничих витрат на вирощування. Прибуток за варіантами досліду був різним та у гібриду кукурудзи Аякс варіював в межах 41773-47064 грн/га, тоді як у гібриду Оржиця $237 \mathrm{MB}$ відповідно 39298-44787 грн/га, що обумовлено нижчим показником урожайності. Аналізуючи ефективність використання добрив 3 мікроелементним складом виявлено, що у гібриду Аякс за проведення

позакореневого підживлення посівів добривами Нутрімікс та Нутрібор (варіанти 2-4) при невисокій їх вартості витрати зросли на 582-1348 грн/га. Варіанти застосування у підживленні добрива МікроМінераліс Кукурудза (варіанти 5-7) показали зростання витрат порівняно 3 контролем на 174-545 грн/га, проте прибуток зріс на 386-1685 грн/га.

Найбільшу

економічну ефективність забезпечив гібрид кукурудзи Аякс за сумісного застосування добрив Нутрімікс, Нутрібор та Мікро-Мінераліс Кукурудза і дворазового підживлення посівів у фенологічні фази 4 та 8 листка. Саме даний варіант досліду продемонстрував найвищу окупність додаткових витрат та прибуток зріс порівняно $з$ контролем на 5291 грн/га.

Здійсненими

економічної вирощування гібриду кукурудзи Оржиця 237 МВ залежно від фону мінеральних добрив та позакореневого підживлення посівів добривами 3 мікроелементним складом в середньому за 2015-2017 роки виявлено, що за урожайністю цей гібрид поступився гібриду Аякс, чим обумовлено i нижчі значення основних економічних показників (вартості валової продукції, прибутку з 1 га та рівню рентабельності) при аналогічних витратах Ha вирощування. 
Крестьянінов Є. В., Єрмакова Л. М., Антал Т. В.

\section{1. Економічна та енергетична ефективність вирощування гібриду} кукурудзи Аякс залежно від фону мінеральних добрив та застосування у підживленні добрив з мікроелементним складом, середнс за 2015-2017 рр.

\begin{tabular}{|c|c|c|c|c|c|c|c|}
\hline $\begin{array}{l}\text { № } \\
\Pi / \Pi\end{array}$ & $\begin{array}{c}\text { Варіант удобрення } \\
\text { (фактор В)* }\end{array}$ & 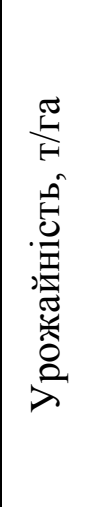 & 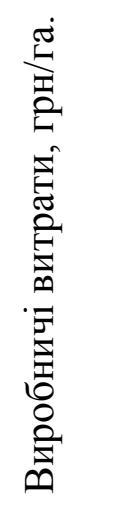 & 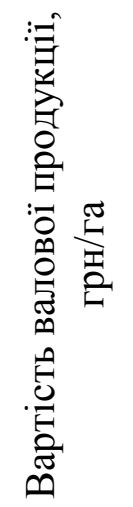 & 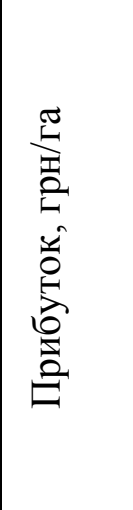 & 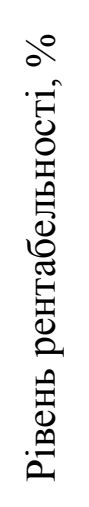 & 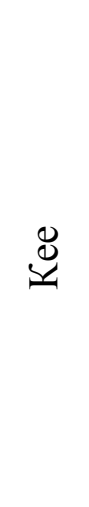 \\
\hline 1 & $\mathrm{~N}_{156} \mathrm{P}_{52} \mathrm{~K}_{52}(Ф \mathrm{OH})$ & 8,91 & 29507 & 71280 & 41773 & 142 & 4,73 \\
\hline 2 & $\begin{array}{l}\text { Фон+Нутрімікс, Нутрібор по 4- } \\
\text { му листку }\end{array}$ & 9,11 & 30089 & 72880 & 42791 & 142 & 4,71 \\
\hline 3 & $\begin{array}{l}\text { Фон+Нутрімікс, Нутрібор по 8- } \\
\text { му листку }\end{array}$ & 9,17 & 30174 & 73360 & 43186 & 143 & 4,48 \\
\hline 4 & $\begin{array}{l}\text { Фон+Нутрімікс, Нутрібор по } 4 \text { та } \\
\text { 8-му листку }\end{array}$ & 9,44 & 30855 & 75520 & 44665 & 145 & 4,76 \\
\hline 5 & $\begin{array}{l}\text { Фон+ Мікро-Мінераліс } \\
\text { Кукурудза по 4-му листку }\end{array}$ & 8,98 & 29681 & 71840 & 42159 & 142 & 4,68 \\
\hline 6 & $\begin{array}{l}\text { Фон+ Мікро-Мінераліс } \\
\text { Кукурудза по 8-му листку }\end{array}$ & 9,03 & 29752 & 72240 & 42488 & 143 & 4,70 \\
\hline 7 & $\begin{array}{l}\text { Фон+Мікро-Мінераліс по } 4 \text { та по } \\
\text { 8-му листку }\end{array}$ & 9,19 & 30052 & 73520 & 43458 & 145 & 4,48 \\
\hline 8 & $\begin{array}{l}\text { Фон+Нутрімікс + Нутрібор + } \\
\text { Мікро-Мінераліс Кукурудза по } 4 \\
\text { та 8-му листку }\end{array}$ & 9,77 & 31096 & 78160 & 47064 & 151 & 4,87 \\
\hline \multicolumn{2}{|c|}{$\begin{array}{l}\text { НІР 0,95, т/га по: фактору А } \\
\text { фактору В } \\
\text { взаємодії АВ }\end{array}$} & $\begin{array}{l}0,15 \\
0,05 \\
0,11\end{array}$ & & & & & \\
\hline
\end{tabular}

*Норма витрат: Нутрімікс - 1 кг/га; Нутрібор - 0,5 кг/га; Мікро-Мінераліс Кукурудза - 1 л/га

Для всебічної оцінки технології вирощування гібридів кукурудзи залежно від досліджуваних чинників проведено порівняння енергії, акумульованої в урожаї із сукупною енергією, що затрачена на вирощування i збирання врожаю. Встановлено, що найвищі енерговитрати на 1 га посіву кукурудзи були у варіантах за застосування позакореневих підживлень посівів кукурудзи та у гібриду Аякс на фоні внесених мінеральних добрив та підживлення сучасними добривами Нутрімікс, Нутрібор та Мікро-Мінераліс Кукурудза по 4 та 8 листку становили 36136-35324 Мдж/га. За зазначеного варіанту ці показники у гібриду Оржиця 237 МВ були в межах 3432735206 Мдж/га. Разом 3 тим варто відмітити і значне зростання виходу енергії 3 урожаєм зерна гібридів кукурудзи при застосуванні сучасних 
Крестьянінов Є. В., Срмакова Л. М., Антал Т. В.

мікродобрив. Найвищі показники у досліджуваних гібридів було отримано за комплексного застосування двох видів добрив у підживленні та дворазової обробки посівів у фенологічні фази 4 та 8 листка. Вони відповідно становили 171952 та 162096 Мдж/га у гібридів Аякс та Оржиця 237 МВ. Основним критерієм енергетичної оцінки вирощування гібридів кукурудзи $\epsilon$ показник енергетичної ефективності (Кеe). Це відношення маси енергії, що міститься в отриманій продукції до енергії, що витрачена на її отримання. В цілому показник Кеe у обох гібридів високий та залежно від виду добрив у гібриду Аякс становив від 4,48 до 4,87 та у гібриду Оржиця 237 MB 4,36-4,72.

2. Економічна та енергетична ефективність вирощування гібриду кукурудзи Оржиця 237 МВ залежно від фону мінеральних добрив та застосування у підживленні добрив з мікроелементним складом, середнє за 2015-2017 pp.

\begin{tabular}{|c|c|c|c|c|c|c|c|}
\hline $\begin{array}{l}\text { № } \\
\Pi / \Pi\end{array}$ & $\begin{array}{l}\text { Варіант удобрення } \\
\text { (фактор В)* }\end{array}$ & 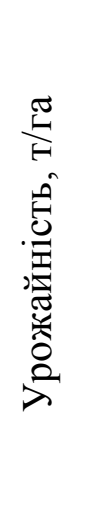 & 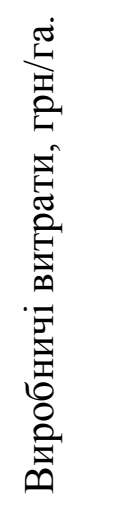 & 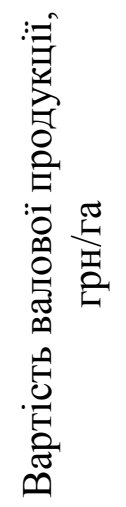 & 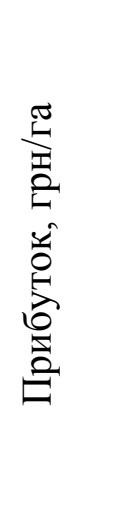 & 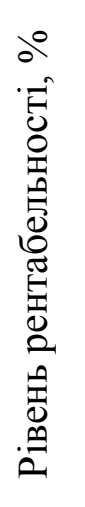 & $\underset{1}{\otimes}$ \\
\hline 1 & $\mathrm{~N}_{156} \mathrm{P}_{52} \mathrm{~K}_{52}($ Фон $)$ & 8,32 & 27262 & 66560 & 39298 & 144 & 4,56 \\
\hline 2 & $\begin{array}{l}\text { Фон+Нутрімікс, Нутрібор по 4- } \\
\text { му листку }\end{array}$ & 8,57 & 27915 & 68560 & 40645 & 146 & 4,56 \\
\hline 3 & $\begin{array}{l}\text { Фон+Нутрімікс, Нутрібор по 8- } \\
\text { му листку }\end{array}$ & 8,64 & 28014 & 69120 & 41106 & 147 & 4,35 \\
\hline 4 & $\begin{array}{l}\text { Фон+Нутрімікс, Нутрібор по } 4 \text { та } \\
\text { 8-му листку }\end{array}$ & 8,88 & 28582 & 70640 & 42058 & 147 & 4,59 \\
\hline 5 & $\begin{array}{l}\text { Фон+ Мікро-Мінераліс } \\
\text { Кукурудза по 4-му листку }\end{array}$ & 8,44 & 27507 & 67520 & 40013 & 145 & 4,53 \\
\hline 6 & $\begin{array}{l}\text { Фон+ Мікро-Мінераліс } \\
\text { Кукурудза по 8-му листку }\end{array}$ & 8,52 & 27619 & 68160 & 40541 & 147 & 4,56 \\
\hline 7 & $\begin{array}{l}\text { Фон+Мікро-Мінераліс по } 4 \text { та по } \\
\text { 8-му листку }\end{array}$ & 8,73 & 27991 & 69840 & 41849 & 150 & 4,36 \\
\hline 8 & $\begin{array}{l}\text { Фон+Нутрімікс + Нутрібор + } \\
\text { Мікро-Мінераліс Кукурудза по } 4 \\
\text { та 8-му листку }\end{array}$ & 9,21 & 28893 & 73680 & 44787 & 155 & 4,72 \\
\hline \multicolumn{2}{|c|}{$\begin{array}{l}\text { НІР 0,95, т/га по: фактору А } \\
\text { фактору В } \\
\text { взаємодії АВ }\end{array}$} & $\begin{array}{l}0,15 \\
0,05 \\
0,11\end{array}$ & & & & & \\
\hline
\end{tabular}

*Норма витрат: Нутрімікс - 1 кг/га; Нутрібор - 0,5 кг/га; Мікро-Мінераліс Кукурудза - 1 л/га 
Агрономія

Крестьянінов Є. В., Срмакова Л. М., Антал Т. В.

Різна реакція гібридів на внесення добрив 3 мікроелементним складом та кратності їх застосування обумовлювали і різницю показників енергетичної ефективності.

\section{Висновок.}

Результати проведених досліджень та визначення економічної і енергетичної ефективності вирощування гібридів кукурудзи Аякс і Оржиця 237 МВ дозволили встановити, що найбільшу економічну ефективність забезпечив

\section{Список використаних джерел}

1. Ефективні рішення вирощування кукурудзи та сої: веб-сайт.URL: https://www.dekalb.ua/novini-tapodii/efektivni-risenna-virosuvanna-

kukurudzi-ta-soi (дата звернення: 24.04.2017)

2. Ільченко, В. Ю. Дослідження енергоємності технологічних операцій догляду за посівами кукурудзи / В. Ю. Ільченко, М. І. Ролдугін, Н. О. Кучмій // Вісник Дніпропетровського державного аграрного університету. Екологія, рослинництво. - 2009. - С. 85-88

3. Каленська С.М., Новицька Н.В., Стрихар А.С., Малеончук О.В., Антал Т.В. Управління процесами формування високоякісного насіння сільськогосподарських культур . Науковий вісник НАУ. 2008. Вип. $123 . \quad$ С. 11-17.

4. Каменщук Б.Д. Агроекологічний вплив умов вирощування на зернову продуктивність гібридів кукурудзи різних груп стиглості. Корми і кормовиробництво. 2006. Вип.56. С. 16-21

5. Мокрієнко В.А., Усатий Г.Ю. Особливості засвоєння поживних речовин гібридами кукурудзи. Землеробство. 2006. C. $12-20$.

6. Пащенко Ю.М., Борисов В.М., Шишкіна О.Ю. Адаптивні i ресурсозберігаючі технології вирощування гібридів кукурудзи. Дніпропетровськ : АРТ - ПРЕС, 2009, 224c.

7. Санін Ю. Технологія підживлення кукурудзи макро- та мікроелементами, їхнє високоврожайний гібрид Аякс за вирощування на розрахунковому фоні мінеральних добрив та проведення дворазового підживлення посівів у фенологічні фази 4 та 8 листка добривами 3 мікроелементним складом Нутрімікс (1,0 кг/га), Нутрібор (0,5 кг/га) та МікроМінераліс Кукурудза (1,0 л/га), що забезпечило прибуток 47064 гнр/га, вихід енергіï 3 урожаєм - 171952 Мдж/га та Keе - 4,87.

значення та застосування в посівах кукурудзи [Електронний ресурс]. - Режим доступу:

http://www.propozitsiya.com/page=146\&itemi $\mathrm{d}=3288$.

8. Циков В.С. Питання підвищення конкурентоспроможності виробництва зерна i насіння кукурудзи в ринкових умовах / В.С. Циков, В.С. Рибка, B.I. Альохін // Бюлетень Інституту зернового господарства. - Дніпропетровськ, 1999. - № 8. - C. 55-59.

9. Khalili M., Naghavi M.R., Aboughadareh A.P., Rad H.N., Effects of Drought Stress on Yield and Yield Components in Maize Cultivars (Zea mays L.). International Journal of Agronomy and Plant Production. Vol. 4 (4):809-812 (2013).

10. Grassini P., Yang H.S., Cassman K.G. Limits to maize productivity in Western Corn-Belt: a simulation analysis for fully irrigated and rainfed conditions Agric. For. Meteorol., 149 (2009), pp. C. 125-126

\section{References}

1. Effective Corn and Soybean Growth Solutions: Website. URL: https://www.dekalb.ua/novini-tapodii/efektivni-risenna-virosuvannakukurudzi-ta-soi (Date of Appeal: Apr 24, 2014) .

2. Ilhenko, V. Yu. Roldugin M.I., \& Kuchmii N.O. (2009). Investigation of energy intensity of technological operations for the care of corn crops. Visnyk Dnipropetrovskoho Ahrarnoho Universytetu [Ecology, plant growing], 85-88 [in Ukrainian] 
Крестьянінов С. В., Єрмакова Л. М., Антал Т. В.

3. Kalenska S.M, Novitskaya N.V., Strihar A.E., Maleonchuk O.V, Antal T.V. (2008). Management of the processes of formation of high-quality seeds of agricultural crops. Naukovyi zbirnyk NAU Scientific herald of NAU, 123. P. 11-17 88 [in Ukrainian]

4. Kamenshchuk, B.D. (200). Agroecological influence of the conditions of cultivation on the grain productivity of corn hybrids of different groups of maturation [Kormy I kormovyrobnytstvo ] 56, 16-21 [in Ukrainian]

5. Mokrienko, V.A, Usatuiy, H.YU. ( 2006). Features of assimilation of nutrients by hybrids of corn. Zemlerobstvo [Agriculture] 18, 12-20 [ in Ukrainian]

6. Pashchenko Yu.M., Borisov V.M, Shishkina O.Yu. (2009). Adaptive and resource-saving technologies of growing hybrids of corn. Dnipropetrovsk: ART PRESS, 224p. [ in Ukrainian]

7. Sanin Yu. Technology of corn rejuvenation by macro- and microelements, their significance and application in corn crops [Electronic resource]. Access mode: http: //www.propozitsiya.com/ Page $=146 \&$ itemid $=3288$. [ in Ukrainian]

8. Tsikov V.S., Rybka V.S., Alyochin V.I. (1999). The issue of increasing the competitiveness of grain and corn seed production in market conditions. Biuleten Instytutu zernovoho hospodarstva [Bulletin of the Institute of Grain Farmin ] 8, 55-59. [ in Ukrainian]

9. Khalili M., Naghavi M.R., Aboughadareh A.P., Rad H.N., Effects of Drought Stress on Yield and Yield Components in Maize Cultivars (Zea mays L.). International Journal of Agronomy and Plant Production. Vol. 4 (4):809-812 (2013).

10. Grassini P., Yang H.S., Cassman K.G. Limits to maize productivity in Western Corn-Belt: a simulation analysis for fully irrigated and rainfed conditions Agric. For. Meteorol., 149 (2009), pp. 125-126

\section{ЭКОНОМИЧЕСКАЯ И ЭНЕРГЕТИЧЕСКАЯ ЭФФЕКТИВНОСТЬ ВЫРАЩИВАНИЯ КУКУРУЗЫ ЗАВИСИМО ОТ МИНЕРАЛЬНЫХ УДОБРЕНИЙ И ВНЕКОРНЕВОЙ ПОДКОРМКИ ПОСЕВОВ Е.В. Крестьянинов, Л.М.Срмакова, Т.В.Антал,}

Аннотация. Цель исследований заключалась в определении экономической u энергетической эффективности технологии выращивания кукурузы за применения минеральных удобрений $N_{158} P_{52} K_{52}$ и подкормки посевов удобрениями Нутримикс (1,0 кг/га), Нутрибор (0,5 кг/га) и Микро -Минералис Кукуруза (1,0 л/га). Применение под кукурузу минеральных удобрений и внекорневой подкормки посевов удобрениями с микроэлементным составом обеспечило условно чистую прибыль на уровне 41773-47064 грн/га, рентабельность 142-151\% и коэффициент энергетической эффективности (Кээ) - 4, 73-4,87 у гибрида Аякс и у гибрида Оржица 237 МВ указанные показатели составили соответственно: 39298-44787 грн/2а, 144-155\% и Кээ 4,56 - 4,72. Такой диапазон показателей обусловлен применением удобрений у подкормке разрозненно и совместно с однои двухразовым применением у фенологические фазы четвертого, восьмого и четвертого и восьмого листьев. Применение удобрений с микроэлементами у внекорневую подкормку обеспечивало повышение энергетической $u$ экономической эффективности вырашивания кукурузы.

Ключевые слова: кукуруза, урожайность, экономическая эффективность, удобрения, рентабельность, прибыль, стоимость продукиии 


\title{
ECONOMIC AND ENERGY EFFICIENCY OF MAIZE CULTIVATION
}

DEPENDING ON MINERAL FERTILIZERS AND FOLIAR FERTILIZATION

\section{Ye. V. Krestyaninov, L. M. Ermakova, T. V. Antal}

\begin{abstract}
The purpose of the research was to determine the economic and energy efficiency of maize cultivation technology for the application of mineral fertilizers N158P52K52 and fertilizing fertilizers with Nutrimix (1.0 kg / ha), Nutribor $(0.5 \mathrm{~kg} /$ ha) and Micro Mineralis Maize (1.0 l/ Ha). Application of mineral fertilizers to corn and non-root fertilization of crops with fertilizers with a trace element contributed net profit at the level of 41773 - $47064 \mathrm{UAH} / \mathrm{ha}$, profitability of 142-151\% and energy efficiency factor (Kee - 4,73-4,87) in the Ajax hybrid and respectively, $237 \mathrm{MB}$ in the hybrid Orzhitsa, the indicated indices were: $39298-44787,144-155 \%$ and 4,56 -4.72 respectively. Such a range of indicators is due to the use of fertilizers in nutrition, distinctly and consistently for one and two single applications in the phenological phases of the 4th, 8th and 4th and 8th leaves. The application of fertilizers with trace elements in foliar nutrition provided a slight increase in the energy and economic efficiency of corn cultivation.
\end{abstract}

Key words: corn, yield, economic efficiency, fertilization, profitability, profit, cost of production 